\author{
ALEKSANDRA SZYMAŃSKA \\ (iD https://orcid.org/0000-0002-3380-5396 \\ Uniwersytet Łódzki \\ Wydział Filologiczny \\ Instytut Rusycystyki \\ Zakład Literatury i Kultury Rosyjskiej \\ 90-226 Łódź \\ ul. Pomorska 171/173 \\ aleksandra.szymanska@uni.lodz.pl
}

\title{
THE DIALOGICAL QUALITY OF THE RUSSIAN POETRY OF THE SILVER AGE: A CASE STUDY OF POEMS ABOUT DON JUAN
}

\author{
ДИАЛОГИЧНОСТЬ РУССКОЙ ПОЭЗИИ \\ СЕРЕБРЯНОГО ВЕКА (НА МАТЕРИАЛЕ \\ СТИХОТВОРЕНИЙ ДОНЖУАНСКОГО КРУГА)
}

The article brings a discussion of three poems of Russian modernist poets that undertake the theme of Don Juan - written by Konstantin Balmont, Valery Bryusov and Nikolai Gumilyov. The purpose is to elucidate the characteristics of the artistic dialogue in the discourse of modernist poetry. Two types of dialogue are discussed: macro- and microdialogue. The former is realised through intertextual forms, the latter - by means of intersubjective forms. When poets refer to the image of Don Juan, one variety of dialogue may well transform into the other.

The author of the paper indicates emphatically that the poems under discussion constitute a chain of transformations of the image of Don Juan: the image as proposed by Balmont is then developed by Bryusov and revaluated by Gumilyov. The semantic core of all the three texts is the image of Don Juan as a wanderer who yields to temptations of transient delights.

Keywords: Don Juan, Silver Age, dialogic quality of literature, Balmont, Bryusov, Gumilyov.

В статье рассматриваются три стихотворения с донжуанской темой, написанные поэтами-модернистами - Дон-Жуан Константина Бальмонта, Дон Жуан Валерия Брюсова и Дон Жуан Николая Гумилева. Статья посвящена специфике художественного диалога в дискурсе модернистской поэзии. Нами рассматриваются два типа диалога - макродиалог, воплощаемый в интертекстуальных формах, и микродиалог, воплощаемый в интерсубъективных формах. В случае обращения поэтами к образу Дон Жуана одна разновидность диалога может трансформироваться в другую.

В статье отмечается и подчеркивается, что стихотворения Бальмонта, Брюсова и Гумилева, образуют цепочку трансформаций образа Дон Жуана, предложенного Бальмонтом, затем развитого Брюсовым и переосмысленного Гумилевым. Семантическим ядром всех 
стихотворений является образ Дон Жуана-странника, который поддается соблазнам мгновенных наслаждений.

Ключевые слова: Дон Жуан, Серебряный век, диалогичность литературы, Бальмонт, Брюсов, Гумилев.

As justly pointed out by Lidia Kolobayeva, the Russian modernist literature was developing not simply under the banner of a decisive and substantial renewal, but also that of re-establishing and expanding the foundations of artistic activity as grounded in universal culture ${ }^{1}$. The creative activity of the Silver age is very much oriented on a cultural dialogue and the dialogic quality becomes one of its key text-generating principles. In the present paper I will discuss two varieties of dialogue that can be identified in the works of modernist poets who take up the image of Don Juan.

The first of these is an example of a macrodialogue, i. e. a dialogue in a "large historical time span" (большое историческое время ${ }^{2}$ ), within culture, embodied in intertextual forms. It is accomplished by opening one's own text to "the word of another" - by including reminiscences of and allusions to plots, images, motives or mythologems ${ }^{3}$. The latter type is microdialogue, i. e. a dialogue between the "I" and "You" in the consciousness of an individual, realised in an inner monologue in intersubjective forms ${ }^{4}$. In such a case the addressee can be a rightful participant of the speech situation, which according to Mikhail Bakhtin happens when the addressee and the sender are not separated in space nor in time from the generated text $t^{5}$. It is worth noting that in some of the poems to be analysed the authors "actively define" the addressee(s) by personifying them. In other poems it is the extra-literary context that helps identify the addressee. In modernist poetry, the dialogue with an individual addressee often transforms into a many-sided "playful" dialogue, a poetic contest for the title of a True Poet ${ }^{6}$.

Let us note that in the event of a writer taking up the image of Don Juan, one variety of dialogue may evolve into the other. An intersubjective dialogue, by appealing to a universal image, turns into a dialogue between texts and - in a broader sense - between cultures. Obviously, the presence of cultural-historical and

1 Л. А. Колобаева, Русский символизм, Москва: Издательство Московского университета 2017, р. 10.

${ }^{2}$ М. М. Бахтин, “К методологии гуманитарных наук”, in: М. М. Бахтин, Эстетика словесного творчества, Москва: Искусство 1979, р. 373.

${ }^{3}$ Т. С. Круглова, “Макродиалог и микродиалог в поэтической культуре Серебряного века", Вестник славянских культур 2009, по. 3 (XIII), р. 60.

${ }^{4}$ Ibid.

${ }^{5}$ М. М. Бахтин, Собрание сочинений: в 7 т., Москва: «Русские словари» 1997, vol. 5, pp. 238-239.

${ }^{6}$ See on this: Т. С. Круглова, “Макродиалог и микродиалог...”, p. 62. 
mythological references or playing with well-known plots and images are an important characteristic of modernist writing. A "double" addressing of a text within the framework of a macrodialogue and microdialogue is, in Tatyana Kruglova's opinion, a defining feature of modernist discourse ${ }^{7}$.

In the present contribution the dialogical framework will be employed to examine three poems of the Russian Silver Age: Konstantin Balmont's “Дон Жуан” ('Don Juan', 1898), Valery Bryusov’s “Дон Жуан” (1900) and Nikolai Gumilyov's “Дон Жуан” (1910). With the quotational references and the subtext created by reminiscences revealed, the texts will be analysed in the context of the admiration and dislike of writers for each other, with the view to shedding new light on the Russian interpretations of the figure of Don Juan which emerged in the ambience of the Silver Age.

The chain of the Don Juan pieces opens with Konstantin Balmont's unfinished long poem “Дон-Жуан” ('Don Juan', 1898), included in the volume Тишина ('Silence', 1898). The poem will be analysed with its epigraph taken as a starting point, since reading Balmont's cycle through the prism of "the word of another" offers a possibility to look at it differently.

An epigraph, as is well known, is a means of introducing into the text an extraneous, non-authorial point of view ${ }^{8}$. On the one hand, the epigraph becomes embedded in an authorial text, on the other, it is distinctly separated as a heterogeneous element, as a quote which preserves a connection with its source ${ }^{9}$. The epigraph plays an intratextual role which requires elucidation. It should be noted that referring to "somebody else's" text is a common practice with Balmont. The fact that in the case in hand he has chosen a little-known source is also hardly surprising. Balmont very rarely employed widely anthologised texts to fulfil this function ${ }^{10}$.

For the epigraph to the poem "Don Juan" Balmont has chosen a fragment from The Atheist's Tragedie; or, The Honest Man's Revenge, by the English dramatist Cyril Tourneur (1575-1626). The motto, in the first publication bilingual, is the following:

${ }^{7}$ Ibid., p. 61.

${ }^{8}$ Н. А. Кузьмина, “Эпиграф в коммуникативном пространстве художественного текста", Вестник Омского университета 1997, по. 2, р. 61.

${ }^{9}$ Е. А. Козицкая, “Эпиграф и текст: о механизме смыслообразования”, in: Литературный текст: проблемы и методы исследования. Сб. науч. тр., Тверь: Тверской государственный университет 1999, vol. 5: «Свое» и «чужое» слово в художественном тексте, [online] https://textarchive.ru/c-2509860-pall.html [DOA 01.09.2020].

${ }^{10} \mathrm{Cf}$. А. С. Серопян, “Внутритекстовая роль эпиграфа в поэзии Бальмонта”, Вестник Вятского государственного гуманитарного университета 2011, no. 2-2, p. 122, [online] https://webcache.googleusercontent.com/search?q=cache:evBI9cyKZScJ:https://cyberleninka. $\mathrm{ru} /$ article/n/vnutritekstovaya-rol-epigrafa-v-poezii-balmonta $+\& \mathrm{~cd}=1 \& \mathrm{hl}=\mathrm{pl} \& \mathrm{ct}=\mathrm{clnk} \& \mathrm{gl}=\mathrm{pl}$ [DOA 29.05.2019]. 
But now I am an emperor of a world,

This little world of man. My passions are

My subjects.

Tourneur

Но теперь я властитель над целым миром, над этим малым миром

человека. Мои страсти - мои подданные.

Тэ рнер ${ }^{11}$

The epigraph has been overlooked by scholars with inexplicable consistency. A commentary can be found in the anthology Дон Жуан русский ['The Russian Don Juan'], where the quote is, however, misattributed to the American theologian, translator and populariser of German religious literature Samuel Turner $(1790-1861)^{12}$. The mistake, partly explained (but not justified) by the convergence of the surnames in the Cyrillic transcription, has become a possible source of confusion for students of Balmont's oeuvre.

The Atheist's Tragedie; or, The Honest Man's Revenge belongs to the genre of revenge tragedy of the turn of the $17^{\text {th }}$ century, the epitome of which is Thomas Kyd's 1582 The Spanish Tragedy ${ }^{13}$. Revenge plays were characteristically underpinned by the ideological scheme in which the pagan concept of "an eye for an eye" was juxtaposed with Christian meekness ${ }^{14}$.

Tourneur's play is nowadays little known to modern audiences, it therefore seems opportune to recount its plot. The protagonist is Charlemont, a stoic characterised by self-control, patience and resistance to pain. His opposite is the atheist D'Amville, greedy and power-seeking ${ }^{15}$. In order to come into possession of inheritance, D'Amville has his brother killed and plans the undoing of his nephew, Charlemont. Honour requires Charlemont to take revenge for his father's death,

${ }^{11}$ К. Д. Бальмонт, “Дон Жуан”, in: К. Д. Бальмонт. Полное собрание стихов, vol. 1, Москва: Изд. Скорпион 1914, [online] https://ru.wikisource.org/wiki/\%D0\%A2\%D0\%B8 \%D1\%88\%D0\%B8\%D0\%BD\%D0\%B0_(\%D0\%91\%D0\%B0\%D0\%BB\%D1\%8C\%D0\%BC\%D 0\%BE\%D0\%BD\%D1\%82_1897)/\%D0\%94\%D0\%9E\#\%D0\%94\%D0\%BE\%D0\%BD\%D1\%8A\%D0\%96\%D1\%83\%D0\%B0\%D0\%BD\%D1\%8A [DOA 29.05.2019].

${ }_{12}$ А. В. Парин, "Примечания”, in: Дон Жуан русский: Антология, ed., introd. and comment. А. В. Парин, Москва: «Аграф» 2000, р. 570.

${ }^{13}$ A discussion in Russian is available in: С. Ю. Будехин, “«Гамлет» Шекспира и трагедия мести: эволюция жанра”, Вестник Омского государственного педагогического университета: Гуманитарные исследования 2014, no. 3 (4), [online] https://cyberleninka.ru/article/n/gamlet-shekspira-i-tragediya-mesti-evolyutsiya-zhanra [DOA 29.05.2019].

${ }^{14}$ Ibid.

${ }^{15}$ А. Н. Горбунов, “Драматургия младших современников Шекспира”, in: Младщие современники Шекспира, еd. А. А. Аникст, Москва: Изд-во Московского университета 1986, [online] http://www.lib.ru/SHAKESPEARE/shks_contemporaries.txt [DOA 29.05.2019]. 
but the young man is dissuaded from it by the father's ghost, who urges him to renounce vengeance. Charlemont has his doubts but ultimately accepts the ghost's argumentation that retribution be left to divine providence that infallibly metes it out after death, if no earlier.

What Balmont has chosen for his epigraph are words pronounced by Charlemont in prison, after suffering a series of calamities. It is referring to the text of the tragedy that makes it possible to disclose the appropriate context against which the phrases should be read. In Tourneur's play the words "But now I am an emperor of a world / [...]. My passions are / My subjects" sound like the stoic's creed. The circumstances in which he finds himself become for him a source of inner strength. He feels like a world's sovereign, able to control his own passions, circumstances notwithstanding. With the view to stressing the superiority of his life philosophy over the thirst for revenge, the protagonist adds that he is able to quell his passions completely:

But now I am an emperor of a world,

This little world of man. My passions are

My subjects, and I can command them laugh,

Whilst thou dost tickle 'em to death with misery ${ }^{16}$.

Charlemont's statement is quoted by Balmont in a shortened form and in the context of a new literary work its meaning is changed. The words which originally expressed the stoic attitude, in "Don Juan" become a life doctrine of a man possessed by passions, the main of which is revenge: on women, on their husbands, on the whole world. Thus, the fragment adopted by Balmont from Tourneur's play now characterises the behaviour of an invulnerable (неуязвимый) rebel and avenger, who declares himself the ruler of the world.

Let us note that the image of Don Juan-the ruler in Balmont's poem becomes associated with the image of the horse rider. A segment depicts a concerted spur of the human and the equestrian figure, in which the horse submits to the rider. This symbolises the victory of the individual element over the chaotic force of natural elements. The poem's epigraph reveals similar meanings. Don Juan is portrayed by Balmont as an "emperor of a world", governing his "passions", striving to bridle chaos.

Balmont's poem is an example of such a dialogue with "someone else's word" in which the interaction with another text results in the meaning of the source utterance being reversed. It seems to be deliberate on Balmont's part, as witnessed by the clipping of the quoted fragment and by the revaluation thereof.

${ }^{16}$ C. Tourneur, The Atheist's Tragedy, [online] https://p.bbdg.net/poem.php?id=10135190 [DOA 29.05.2019]. 
In the history of the Russian poetry of the turn of the $20^{\text {th }}$ poetry and in the vicissitudes of Russian symbolism Balmont's name is closely associated with that of Valery Bryusov. Bryusov was influenced by Balmont from the mid-1890s. Having acknowledged the latter's primacy in literature and having gone through a period of infatuation, toward the beginning of the 1900s Bryusov became less enthusiastic and then went on to express quite severe criticism of Balmont's poetry. Bryusov's sonnet “Дон Жуан” (1900) is connected with its author's attitude towards Balmont's oeuvre and personality.

Bryusov had been acquainted with Balmont's "Дон-Жуан" yet before the poem's publication in 1898, as is confirmed by diary records dated November $1897^{17}$. These diary entries testify to a beginning of a turn in the relationships between the two poets, apparently connected with the fact that some of Balmont's poetic ideas triggered Bryusov's jealousy. The object of "envy" were the fragments of what Balmont planned as a long poem "Дон-Жуан”. Bryusov's diary entries for subsequent days disclose the reasons behind the poets' falling out ${ }^{18}$. It will not be amiss to note that Bryusov discerned in Balmont a desire to exact revenge on himself (Bryusov), for having "betrayed" the ideal of the poet. This way, the theme of vengeance, brought up by Balmont in "Дон-Жуан" and the image of an avenger created by him entered real life and have become one of Balmont's masks.

The relations between the two, who had yet recently been friends, began changing in the period when Balmont, having published Тишина, was heading towards Горящие здания ('Buildings in flames', 1900), while Bryusov was working on the volume Tertia Vigilia, into which his sonnet “Дон Жуан” would be incorporated. As can be ascertained on basis of drafts, Bryusov initially chose for an epigraph the phrase "La luna llena" from the opening line of Balmont's "Дон-Жуан". This is not his only reference to his contemporary. A whole section of his new volume was given by Bryusov the intertitle "Близким" ['To my dear ones']. Within this cycle a central place was reserved for Balmont. The cycle includes the epistle “К. Д. Бальмонту" ['To K.D. Balmont'], which constitutes a reply to the former's poems from the volume Горящие здания, as well as a number of biting parodies on Balmont's verse, ridiculing his self-admiration, ostentatious exoticism, etc.

${ }^{17}$ See about this in more detail: “Переписка с К. Д. Бальмонтом 1894-1918”, in: Валерий Брюсов и его корреспонденты, Москва: Литературное наследство 1991, vol. 98, Part 1, pp. 30239, [online] http://litnasledstvo.ru/site/book/id/90 [DOA 04.06.2019].

18 "I wrote to Balmont today, saying that I will be free in the evening. He came to visit. I think he wanted to take it out on me. He had wanted so much to see me, in his imagination he had made me so desirable. In his letters he used to say that of the whole of Russia he only needed me. Well, naturally, the actual thing is not what one has dreamt out! And what's more, much of what Balmont strives for will never be acceptable for mе.” В. Я. Брюсов, Дневники. Автобиограбическая проза. Письма, ed. and introd. Е. В. Иванова, Москва: ОЛМА-ПРЕСС Звездный мир 2002, p. 46, entry for the $21^{\text {st }}$ of November 1897. 
Bryusov's poem “Дон Жуан” is included in the cycle “Любимцы веков". Among the eponymous "Favourites of the ages", the cycle features, alongside Don Juan, the images of Solomon, Ramses, Orpheus, Cassandra, Cleopatra, Iseult and others. Bryusov frequently filled his verse with historical and mythological motives, names of divinities and heroes. As observed by Natalya Matveyevskaya, the images of Alexander the Great, Ramses, Circe, Cleopatra, Don Juan represent a regular complex of intentions, "revealing the essence of the 'ruler', indicating their boundless possibilities: the ability to conquer, to cast a spell, to enchant - to subject to their will and to quench the incessant desire of being"19. As for the image of Don Juan-the ruler, Bryusov apparently owes it to Balmont.

The dialogical character is noticeable in the very opening lines of Bryusov's sonnet:

Да, я - моряк! искатель островов,

Скиталец дерзкий в неоглядном море ${ }^{20}$.

Yes, I'm a sailor! A wanderer of the seas,

In endless waves a seeker of strange isles ${ }^{21}$.

(Trans. by Tamara Vardomskaya)

The lines may refer to Balmont's image of a "pirate", sailing across "waste waters", although, admittedly, the figures of a sailor and of a pirate are not exactly the same. The image of a pirate embodies a traditional concept of a male who is strong, fearless, contemptuous of death, independent, disregarding moral norms and violating social taboos. Pirates are conquerors of dangerous waters, discoverers of exotic lands. The image of a sailor, in turn, due to its romantic associations triggered by the sea as element, acquires such attributes as courage, endurance, a dismissive attitude towards the "landlubbers' life". Bryusov's motives of sea voyages, quests and wanderings as a symbolic description of a quest for love perfectly fit the context not only of Russian poetry, but of world poetry in general ${ }^{22}$.

${ }^{19}$ Н. Г. Матвеевская, “Антиномия «пределов» и «беспредельности» в лирике В. Брюсова (к вопросу о структуре образа лирического субъекта)", Вестник Нижегородского университета им. Н. И. Лобаческого 2009, по. 1, р. 256.

${ }^{20}$ В. Я. Брюсов, “Дон Жуан”, in: В. Я. Брюсов, Собрание сочинений в 7 mомах, vol. 1: Стихотворения 1892-1909, Москва: Художественная литература 1973, [online] https://ruslit. traumlibrary.net/book/bryusov-ss07-01/bryusov-ss07-01.html\#fbcont [DOA 16.04.2020].

${ }^{21}$ V. Bryusov, "Don Juan", trans. by T. Vardomskaya, [online] https://ruverses.com/valery-bryusov/don-juan/1077/ [DOA 15.12.2020].

${ }^{22}$ Ю. В. Тарантул, “Сонеты В. Я. Брюсова и Н. С. Гумилева о Дон Жуане: сравнительно-реконструктивная характеристика”, in: Брюсовские чтения 1996 года, ed. С. Т. Золян, Ереван: Лингва 2001, [online] https://studylib.ru/doc/3725341/-moskva--sonety-bryusova-in.s.gumileva-o-don-zhuane [DOA 06.06.2019]. 
Overcome by the unquenchable desire for the "new" and "other", Bryusov's Don Juan makes his conquests with women so as to master "sacred depths" (святая глубина). He takes possession of women's souls trying to get closer to an "unknown secret" (безвестная тайна). The passion to which Bryusov's Don Juan yields is precisely that of possession. It turns out that love and death are two passions that will help the lyrical subject commune with the Absolute. The communion can, however, only be momentary. Destroying a woman after a woman for the sake of touching the "sacred depth", Don Juan becomes the hub of the idea of an "eternal moment":

В любви душа вскрывается до дна,

Яснеет в ней святая глубина,

Где все единственно и неслучайно.

Да! я гублю! пью жизни, как вампир!

Но каждая душа - то новый мир

И манит вновь своей безвестной тайной ${ }^{23}$.

In love, souls open to the farthest side,

And brighter grow their sacred depths so wide

Where all things are deliberate and rare.

Yes! I destroy! Like Vampyre, lives I drain!

But each soul offers a new world again,

And tempts anew with secrets undeclared.

(Trans. by Tamara Vardomskaya)

The concept of eternal movement, eternal striving, the superiority of the process over the result make Bryusov's character similar to Balmont's.

The third Don Juan text, from the pen of Nikolai Gumilyov, is, like Bryusov's, a sonnet, and a result of a literary dialogue. Gumilyov's volume Жемчуга ('Pearls', 1910), incorporating the sonnet “Дон Жуан”, was equipped with the following dedication: "For my teacher Valery Bryusov” („Посвящается моему учителю Валерию Брюсову"). This dedication, with the word "teacher", shaped the reception of Gumilyov's book of verse. On basis of the correspondence between Gumilyov and Bryusov it can be established that Gumilyov considered Жемчуга the conclusion of his "apprenticeship" as a writer ${ }^{24}$. As a consequence of the poets'

${ }^{23}$ В. Я. Брюсов, “Дон Жуан”..., [DOA 16.04.2020].

${ }^{24} \mathrm{Cf}$. the letter of the $21^{\text {st }}$ of April 1910: "I do not know if you would find me worthy of becoming knighted, yet it would be very important for me to hear a word of advice from you, given that with Жемчуга a big cycle of experience comes to a close for me and I will now be striving towards 
coming to a disagreement after the publication, in the 1918 re-edition of Жемчуга the dedication was removed.

As can easily be seen, the poems of Balmont, Bryusov and Gumilyov, as interpretations of the myth of Don Juan, build a chain of transformations of an image which is proposed by Balmont, then developed by Bryusov and revaluated by Gumilyov. The semantic core of all the three poems remains the image of Don Juan - the wanderer who yields to the temptations of transient delights. Let us note that Gumilyov, when characterising Don Juan, continues the line of depicting him as a rider and a seaman:

\section{Моя мечта надменна и проста:}

Схватить весло, поставить ногу в стремя ${ }^{25}$.

My fantasy is simple as it's proud:

To grasp an oar, to put my feet in stirrups ${ }^{26}$.

These concurrences notwithstanding, Gumilyov offers a take on the image that is distinct from that of his two predecessors. The poet takes up the legend according to which after his eventful life, Don Juan entered a convent. Gumilyov's lyrical subject contemplates repentance and salvation, but puts it off till later. As long as he is young, strong and healthy, he intends to "cheat the sluggish time" (обмануть медлительное время).

Beside the motive of repentance, Gumilyov's sonnet foregrounds the motive of the "I"'s loneliness. The loneliness results not so much from the impossibility to reach the Absolute, as from Don Juan's lifestyle. Gumilyov's character considers himself an "unnecessary atom" (ненужньй атом), since on the earth he will leave behind neither offspring, nor any dear people. Besides oblivion, he fears silence, which, as is well known, accompanies thinking processes. The inclination for self-reflection distinguishes him from his predecessors. In Balmont's and Bryusov's poems Don Juan is primarily energy, impact, a wild element.

Let us note that the analysed poems illustrate such a form of dialogue in which the addressee turns out to be a fellow writer. The spectrum of possible reactions

different, new things. What these new things are to be is not as yet clear to me. [...] Nonetheless, I repeat that this is not clear for me and I do expect from you some kind of indication, a hint, which I, perhaps, will not grasp immediately, but which will spring in my consciousness when needed. It has been so on a number of occasions and I know that whatever I have achieved, I owe it to you." Н. С. Гумилев, Pro et contra, ed. Ю. В. Зобин, Москва: РХГИ 2000, [online] https:/gumilev. ru/notes/42/ [DOA 01.09.2020].

${ }^{25}$ Н. С. Гумилев, “Дон Жуан”, in: Н. С. Гумилев, Полное собрание сочинений в десяти томах, vol. 1: Стихотворения. Поэмы (1902-1910), Москва: Воскресенье 1998, р. 272.

${ }^{26}$ Translated for the sake of the present article - M. K. 
encompasses admiring the addressee's personality, perceiving such admiration as a stage in one's spiritual growth, as well as the proclamation of a breakup. Moreover, it should be noted that the conflict is, as a rule, mythologised.

The interpretations of Don Juan created by modernist poets in a new sociocultural reality contribute to the universal image and enrich it with new meanings. At the same time, the new interpretation preserves the semantic constants of the image which have their basis in a rich cultural tradition.

Translated from Russian by Marta Kaźmierczak

\section{References}

Bakhtin, Mikhail M. K metodologii gumanitarnykh nauk. In: Bakhtin, Mikhail M. Estetika slovesnogo tvorchestva. Moskva: Iskusstvo, 1979.

Bakhtin, Mikhail M. Sobranie sochinenii: v 7 t. Vol. 5. Moskva: Russkie slovari, 1997.

Bryusov, Valerii Ya. Dnevniki. Avtobiograficheskaya proza. Pisma. Moskva: OLMA-PRESS Zvezdnyi mir, 2002.

Bryusov, Valerii. “Don Juan”, trans. by T. Vardomskaya, https://ruverses.com/valery-bryusov/donjuan/1077/.

Bryusov, Valerii Ya. Don Zhuan. In: Bryusov, Valerii Ya. Sobranie sochinenii: v 7 t. Vol. 1: Stikhotvoreniya 1892-1909. Moskva: Khudozhestvennaya literatura, 1973. https://ruslit. traumlibrary.net/book/bryusovss07-01/bryusov-ss07-01.html\#fbcont

Budekhin, Sergei Yu. “'Gamlet' Shekspira i tragediya mesti: evolyutsiya zhanra”. Vestnik Omskogo gosudarstvennogo pedagogicheskogo universiteta. No. 3 (4) (2014): 44-46. https://cyberleninka. $\mathrm{ru} /$ article/n/gamlet-shekspira-i-tragediya-mesti-evolyutsiya-zhanra

Gorbunov, Andrei N. Dramaturgiya mladshikh sovremennikov Shekspira. In: Mladshie sovremenniki Shekspira, ed. A. A. Anikst. Moskva: Izd-vo Moskovskogo universiteta, 1986. http://www.lib. ru/SHAKESPEARE/shks_contemporaries.txt

Gumilev, Nikolai S. Don Zhuan. In: Polnoe sobranie sochinenii: v 10 t. Vol. 1: Stikhotvoreniya. Poemy (1902-1910). Moskva: Voskresene, 1998: 272.

Gumilev, Nikolai S. Pro et contra. Moskva: RKhGI, 2000.

Kolobaeva, Lidiya A. Russkii simvolizm. Moskva: Izdatelstvo Moskovskogo universiteta, 2017.

Kozitskaya, Ekaterina A. Epigraf i tekst: o mekhanizme smysloobrazovaniya. In: Literaturnyi tekst: problemy $i$ metody issledovaniya. «Svoe» $i$ «chuzhoe» slovo v khudozhestvennom tekste. Tver: Tverskoi gosudarstvennyi universitet, 1999. https://textarchive.ru/c-2509860-pall.html

Kruglova, Tatyana S. "Makrodialog i mikrodialog v poeticheskoi kulture Serebryanogo veka". Vestnik slavyanskikh kultur. No. 3 (2009): 60-64.

Kuzmina, Natalya A. "Epigraf v kommunikativnom prostranstve khudozhestvennogo teksta". Vestnik Omskogo universiteta. No. 2 (1997): 60-63.

Matveevskaya, Natalya G. “Antinomiya 'predelov' i 'bespredel'nosti' v lirike V. Bryusova (k voprosu o structure obraza liricheskogo subekta)". Vestnik Nizhegorodskogo universiteta im. N. I. Lobacheskogo. No. 1 (2009): 255-259.

Parin, Aleksei V. Primechaniya. In: Don Zhuan russkii: Antologiya, ed. A. V. Parin. Moskva: «Agraf», 2000: 563-573.

Perepiska s K. D. Balmontom 1894-1918. In: Valerii Bryusov i ego korrespondenty, Vol. 98. Moskva: Literaturnoe nasledstvo, 1991. http://litnasledstvo.ru/site/book/id/90 
Seropyan, Avetis C. "Vnutritekstovaya rol epigrafa v poezii Balmonta". Vestnik Vyatskogo gosudarstvennogo gumanitarnogo universiteta. No. 2-2 (2011): 122-126. https://webcache. googleusercontent.com/search?q=cache:evBI9cyKZScJ:https://cyberleninka.ru/article/n/ vnutritekstovaya-rol-epigrafa-v-poezii-balmonta $\& \mathrm{~cd}=1 \& \mathrm{hl}=\mathrm{pl} \& \mathrm{ct}=\mathrm{clnk} \& \mathrm{gl}=\mathrm{pl}$

Tarantul, Yuliya V. Sonety V. Ya. Bryusova i N. S. Gumileva o Don Zhuane: sravnitelno-rekonstruktivnaya kharakteristika. In: Bryusovskie chteniya 1996 goda, ed. S. T. Zolyan. Erevan: Lingva, 2001. https://studylib.ru/doc/3725341/-moskva--sonety-bryusova-i-n.s.gumileva-o-don-zhuane Tourneur, Cyril. The Atheist's Tragedy. https://p.bbdg.net/poem.php?id=10135190

\begin{tabular}{|l|l|}
\hline Co Comative & $\begin{array}{l}\text { ○ by the author, licensee Lodz University - Lodz University Press, Lodz, } \\
\text { Poland. This article is an open access article distributed under the terms and } \\
\text { conditions of the Creative Commons Attribution license CC-BY-NC-ND 4.0 } \\
\text { (https://creativecommons.org/licenses/by-nc-nd/4.0/) }\end{array}$ \\
\hline
\end{tabular}

